\title{
P04.58. Inner congruence, mindfulness and positive mood in experienced yoga practitioners
}

\author{
A Hedtstück, T Ostermann * A Büssing \\ From International Research Congress on Integrative Medicine and Health 2012 \\ Portland, Oregon, USA. 15-18 May 2012
}

\begin{abstract}
Purpose
Besides physical movements, yoga involves mental techniques which are considered to be essential for its effectiveness. However, active participation of the practitioners seems to be essential. This attitude can be operationalized and measured with the "Inner Congruence and Peaceful Harmony" (ICPH) questionnaire. In a previous study, we have shown that ICPH can be predicted solely by the acceptance component of mindfulnes. Now we investigated whether and how variables of mental stability change with respect to ICPH.
\end{abstract}

\section{Methods}

Prospective analysis of data from 160 individuals participating in a two-year yoga teacher training (Yoga Vidya: $91 \%$ women; mean age $41 \pm 8$ years; mean duration of yoga practice $39 \pm 53$ months). Standardized questionnaires were administered at the start (t1), 3 months ( $\mathrm{t} 2)$, and 6 months (t3) later which comprised of Inner Congruence and Peaceful Harmony (ICPH), Mindfulness (FMI), Life Satisfaction (BMLSS), Positive Mood States (POMS/ASTS), health related Quality of Life (SF-12), Light-Heartedness / Easiness (LHE), and Aspects of Spirituality (ASP).

\section{Results}

During the course of intensified yoga practice, particularly LHE (Cohen's $d=.73)$ and mindfulness $(\mathrm{d}=.58)$ increased significantly $(\mathrm{p}<.0001$; Friedman $)$, while positive $\operatorname{mood}(\mathrm{d}=.29)$, mental health $(\mathrm{d}=.27)$ and ICPH $(\mathrm{d}=.22)$ increased only slightly. With respect to ASP, conscious interactions (ASP; $\mathrm{d}=.34$ ) and religious orientation (ASP, $\mathrm{d}=.34$ ) increased significantly $(\mathrm{p}<.01)$. Individuals with primarily low ICPH scores $(28 \%)$ showed a significant development in mindfulness $(\mathrm{d}=.78)$ and LHE

University of Witten/Herdecke, Herdecke, Germany $(\mathrm{d}=.77)$, while those with moderate ICPH (53\%) had a small increase of mindfulness $(\mathrm{d}=.47)$, but a strong increase in LHE $(\mathrm{d}=.93)$. Those with primarily high ICPH (19\%) showed only small increases in mindfulness $(\mathrm{d}=.35)$ and LHE $(\mathrm{d}=.42)$.

\section{Conclusion}

Even in already experienced yoga practitioners, positive mood and mindfulness increased significantly. One could suggest that ICPH represents a trait which may be developed to facilitate the beneficial effects of mindfulness on mental stability. Further investigations enrolling patients with chronic diseases are required.

Published: 12 June 2012

\section{doi:10.1186/1472-6882-12-S1-P328}

Cite this article as: Hedtstück et al.: P04.58. Inner congruence,

mindfulness and positive mood in experienced yoga practitioners. BMC

Complementary and Alternative Medicine 2012 12(Suppl 1):P328.

Submit your next manuscript to BioMed Central and take full advantage of:

- Convenient online submission

- Thorough peer review

- No space constraints or color figure charges

- Immediate publication on acceptance

- Inclusion in PubMed, CAS, Scopus and Google Scholar

- Research which is freely available for redistribution
( 2012 Hedtstück et al; licensee BioMed Central Ltd. This is an Open Access article distributed under the terms of the Creative Commons Attribution License (http://creativecommons.org/licenses/by/2.0), which permits unrestricted use, distribution, and reproduction in any medium, provided the original work is properly cited. 